\title{
The Impact of Social Housing Program on the Demand for Housing in Turkey: A Cross-Section Analysis
}

\author{
Abuzer Pınar ${ }^{1} \&$ Murat Demir ${ }^{2}$ \\ ${ }^{1,2}$ Harran University, Faculty of Economics and Administrative Sciences, Şanlıurfa, Turkey. \\ Correspondence: Abuzer Pınar, Harran University, Faculty of Economics and Administrative Sciences, Osmanbey \\ Kampüsü, Şanlıurfa, Turkey.
}

Received: May 18, 2016

Accepted: May 31, 2016

Available online: June 16, 2016

doi:10.11114/aef.v3i4.1678

URL: http://dx.doi.org/10.11114/aef.v3i4.1678

\begin{abstract}
This paper analyses the demand for housing in Turkey, incorporating public housing provision. The housing provision by Housing Development Administration of Turkey (HDA-the original name is Toplu Konut İdaresi-TOKİ) has been argued whether it effectively provides social housing for the poor. The question has been investigated by a model of demand for housing. A model of housing is established, wherein the demand for housing is assumed to be a function of income, price and population. Foreigners' demand and the ratio of mortgage credits have been included as explanatory variables. To test the impact of housing provision by HDA, the ratio of total houses provided by HDA has been included in the model. The model has been tested by provincial-based data. The results show that the regional income and wealth, population, and foreigners' demand have positive impact, and the price has negative impact on the demand for housing, while the mortgage loans appeared to be insignificant. Public housing towards low-income groups does not create any impact on the housing market, while the ones targeting middle-income groups seem to substitute $15 \%$ of market supply. The originality of this paper is twofold: Firstly, the paper establishes an original model to analyses the demand for housing in Turkey. Secondly, the impact of HDA housing is of value to analyze to what extent the Agency is a vehicle for social housing.
\end{abstract}

Keywords Turkey, Social housing programs, Public housing provision, Demand for housing

\section{Introduction}

Housing sector is of importance in terms of economic, social and financial aspects in all economies, and particularly in developing countries due to huge demand for houses as a basic need and an instrument for wealth accumulation (Coşkun, 2010; OECD, 2011). On the other hand, low income groups may face serious difficulties to access adequate houses, and a role may be unavoidable for governments to intervene in the housing sector. Governments in many developed and developing countries implement public housing programs in which houses are either owned or allocated by a public body (Chen et al., 2014; Sengupta, 2015). Such a policy is employed either as an expansionary economic policy or as a social program to increase the living standard of the poor. This intervention may be a policy formulation such as the regulation of the mortgage market or subsidized interest rates. A step further is the direct government intervention to provide adequate accommodation for citizens on low prices or rents.

Government intervention in housing sector sometimes appears as direct house provision, and sometimes by indirect instruments such as tax incentives, adequate mortgage credits programs, zoning plans, and provision of low cost building materials. In the developing countries such public policies have important implications both for producers and buyers in housing sector (Quigley, 2006).

Housing policy is a controversial issue as governments may intervene in the sector as a social policy tool to provide accommodation for poor or the intervention may take place as an economic issue to correct market failure. So, two main views are to be considered in terms of housing sector: First is that housing may be regarded as an economic or investment good (Tse et al., 1999). Secondly, housing may be viewed as a social good as a vehicle to satisfy accommodation needs of people (Davidson, 1999). The first approach would require least intervention whereas the second may force more radical intervention, depending on the rate of poverty (Olotuah and Bobadoye, 2009). The more important issue is that a public housing policy should be clear in target. Housing policy ought to be inspected whether it targets the poor, and if so, whether it creates any distortion in the housing market. 
A justification for publicly provided housing would be its real effect on economic units. If the public housing programs simply transfer resources to the units that would be housed even in the absence of such a program, then the program should be regarded as wasteful and ineffectual. This is a type of crowding out effect well-known in economics. Most of the literature on this field is related to the US cases, analyzing the housing programs mainly implemented in 1960s and 1970s. Some recent articles investigate the impact of public housing programs in Korea, Hong Kong, and China.

A case study of US found that on average three government-subsidized units displace two units that would otherwise have been provided by the private market. It was also found that there was less crowd out in more populous markets, and more crowd out in places where there is less excess demand for public housing (Sinai and Waldfogel, 2005). Rental and homeownership units in the public sector constitute 50 percent of the entire housing stock in Hong Kong. Wong (2002) argues that the massive redistribution of housing resources did not improved inequality in Hong Kong, because the public sector housing policy failed to target scarce public resources at the lowest income segments. An empirical analysis for Korea shows that public and private housing investment Granger-cause each other with an asymmetric pattern; and the crowding-out effect rises with the housing availability ratio; it grows rapidly as the housing availability ratio gets closer to $100 \%$ (Lee (2007). Chen and Nong (2016) examines why and how public housing provision may affect the supply of market-based housing in urban China. Their empirical results show that the supply of public housing has moderate crowding-out effect on the supply of market housing in China, and the crowding-out effect varies substantially under different scenarios.

The housing sector in Turkey faces serious difficulties due to rapid urbanization as other similar industrializing countries. Wage level makes it difficult for people to cope with high rents and house prices. The mortgage system does not work due to low income level, and long-term credits are not provided (Yetgin and Lepkova, 2007). In fact, mortgage system is an effective way to cope with the financial bottle-neck in housing sector, and the mortgage law created high expectation in public. ${ }^{1}$ However, high inflation rates, high and volatile interest rates, vulnerability of financial markets and macroeconomic indicators did not allow an efficient implementation of the system. The interest rates in the developed countries are much below unity, and inflation rates are quite low. Unless this problem is somehow solved, the industrialization process will face serious constraints. Public policies towards housing sector are of importance in this sense. Social housing is a way to cope with this housing shortage.

In this paper, we construct a demand model for housing incorporating public housing provision. The determinants of demand for housing vary according to incentive for owning a house (De Leeuw, 1971; Shiller, 2007; Watson, 2013). Given that housing is a basic need for dwelling, the population growth would directly increase the demand for housing. Depending on the environment and quality of houses, the income and prices naturally affect the demand, however, being a basic need, the income and price elasticity are not expected to be high (Lee and Kong, 1977; Glindro et al., 2011). It should be noted that as household incomes rise, people tend to move to better dwellings. Also as an instrument for wealth accumulation, interest rates, the gains from alternative saving instruments, and tastes would also affect the housing demand.

The rest of the paper is as follows: Section 2 provides an overview of the housing sector in Turkey. Section 3 constructs a model of demand for housing, while the data and empirical analysis are presented in section 4 . Some conclusions and further research are discussed in the last section.

\section{An Overview of Housing Sector in Turkey}

High rates of population growth and urbanization lead the increasing demand for housing in Turkey. Apart from population growth rate and urbanization, there are some other reasons behind the increase in the demand for housing. The shortage of regulated lands seems to be an important constraint on the production of housing. Also the inadequate mortgage credits, unemployment, problems with income distribution, per capita income level are other factors creating pressure on housing supply.

There is not much to say for social housing in the period started from 1950 to 2000 . This period can be characterized by rapid urbanization, and hence the regulation for housing are not sufficient and the existing legal framework has not been implemented sufficiently. The problem was mainly the insufficient housing in this period (Yetgin and Lepkova, 2007). The need for housing led people to live in slums, majority were in illegal status. After the 2000s, the problem has been put as low quality houses, rather than the supply shortage. Housing Development Administration of Turkey (HDA-TOKİ in Turkish) has been concentrated on the housing supply for the middle- and low-income groups.

Political stability is as important as economic stability in the development of housing sector (Ören and Yüksel, 2013). Turkey faced a massive financial crisis in 2001: more than 20 banks failed, thousands of companies closed down, the unemployment increased, and budget deficits reached to about 14 percent of GDP. Structural reforms in the aftermath of

\footnotetext{
${ }^{1}$ Mortgage Law No 5582, 06 March 2007.
} 
2001 crisis changed the risk perception in Turkey. Global investors have been more interested in Turkey, and the banks had the opportunity to provide more funds for housing sector. The mortgage loans have increased by about $7 \%$ in the period 2003-2005, and the house-related debts increased by about 50\%. The expansion of funds in the era after the 2001 crisis provided opportunity for mortgage loans as well. The demand for housing and the prices rose.

The earthquake took place in 1999 provoked the debates in housing sector. The houses without building permit or the "fixed" permits, and the corruption in construction due to lack of audit, inspection have been subject to tempered debates. Also, the financial crises in 2001 in Turkey (and the 2008 global crisis) showed that the mortgage system can be quite vulnerable, as the households might not be able to pay mortgage installments (Coşkun, 2011).

The cultural transformation also affects the housing market. Rapid growth in population, urbanization (many cities exceed 1 million) increase the gap in housing sector. There is an increasing tendency in atomic family; youngsters leave their family in early ages (due to personal freedom, education, work etc.) increase the demand for housing. The housing supply in Istanbul and the coasts may have been come to a threshold; however there is a supply shortage in other rapidly growing cities. The public policies towards housing thus are of importance.

The housing stock in 2000 is about 16 million according to the Turkish Statistical Institute (TSI), about $84 \%$ in urban areas. About 33\% has occupancy permit. In the period 2001-2013, about 5,5 million houses have been constructed by building permit. Since 2006, 500 thousands houses have been constructed every year. The fluctuations in exchange rates and rise in interest rates decreased the construction by about $20 \%$ in 2011, and this has slightly increased in 2012, and rose in the following years again by about $79 \%$. This rise came through by the decreased cost of finance, and the expected increase in VAT on new houses. Thus, there seems to be about 22 million houses at the time being. The demand for housing is expected to rise, as the population over 30s is expected to rise from 38,8 million in 2013 to 47,1 million in ten years' time. Hence, the number of houses is expected to rise to over 25 million, and the expected increase in the demand for housing is about 450 thousands annually on average. Some estimates are even higher. GYODER expect the need for extra housing by 7,7 million, which means 700 thousands extra houses every year (Smith, 2012).

About $24 \%$ of house purchases took place in Istanbul, 15\% in Ankara, and 7\% in İzmir in the period 2008-2012. The purchase of foreigners rose about $9 \%$ annually in the past decade. Istanbul is expected to be among the most preferred metropolitan in Europe. Meanwhile, the prices in housing sector rose about $10 \%$ annually due to the interest rates decline and VAT increases. The correlation between house prices and rents is about 0.99 .

The ratio of mortgage loans to GDP is about 5,6\% and 6\% respectively in 2011 and 2012. This ratio is about 52\% in EU-27. The ratioof mortgage loans to the households' total loans is about $50 \%$ (50\% in 2006 , and $45 \%$ in 2013$)$. The ratio has decreased in the aftermath of the 2008 global crisis. The government declared rent subsidy for 18 months and lower rate interest for houseowners particularly in the earthquake areas. However all those partial policy implementations are not enough to fuel the mortgage loans because of the volatility in economic indicators and low ability to pay compared with the monthly installments.

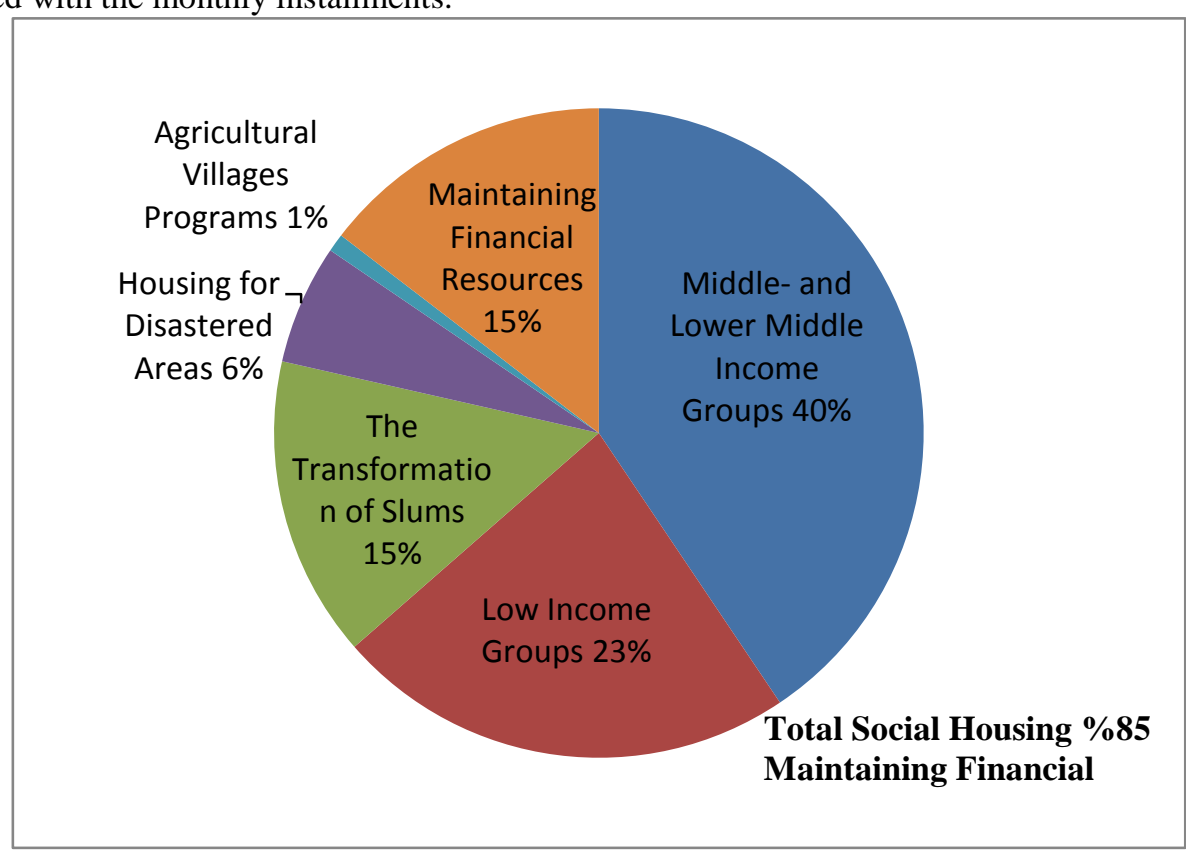

Figure 1. The Implementations by HDA in Turkey (2002-2014) 
The performance of HDA in Turkey in the period of 2002-2014 is as follows: 631,141 thousand houses has been provided; about $23 \%$ for poor, $40 \%$ for middle- and lower-middle income groups, $15 \%$ for the transformation of slums, $6 \%$ for disaster areas, and $1 \%$ for agricultural villages programs. So, the ratio of social housing is about $85 \%$. The rest $(15 \%)$ consists of houses produced to maintain financial resources, and those are mainly provided to high income groups. This makes a sizable portion compared with the period 1984-2001; only about 43 thousands houses produced and credit support given to cooperatives (TOKİ, 2014).

The construction and housing sector is also important for macroeconomic performance. The share of government in the housing sector investments is about $2,4 \%$ after 2010 , and the ratio of housing investment in total public investment is above $11 \%$. The sector provides sizable employment, as the share of employment in the construction sector is about $7,4 \%$. The ratio of housing in the construction sector is $75 \%$ in the period $2005-2014$.

Table 1. The Ownership of Housing in EU and Turkey

\begin{tabular}{ccccc}
\hline & Owned $\%$ & Rented $\%$ & Social Houses $\%$ & Total Social Houses \\
\hline Netherlands & 54 & 11 & 35 & 2400000 \\
Austria & 55 & 20 & 25 & 800000 \\
Denmark & 52 & 17 & 21 & 530000 \\
Sweden & 59 & 21 & 20 & 780000 \\
UK & 70 & 11 & 18 & 3983000 \\
France & 56 & 20 & 17 & 4230000 \\
Ireland & 80 & 11 & 8 & 124000 \\
Germany & 46 & 49 & 6 & 1800000 \\
Hungary & 92 & 4 & 4 & 167000 \\
Turkey* & 67 & 26 & 2 & 536649 \\
\hline
\end{tabular}

Source: Whitehead and Scanlon (2007: 9), and TÜIK (2013).

*The social houses in Turkey include the provision by HDA in the period 2002-2014.

Compared with the EU countries the ratio of tenants in social houses is quite low in Turkey. Housing and rents account for about $27 \%$ of total household consumption spending in the period 2002-2013. Despite that, a ratio below 30\% seems to be acceptable compared with the average of other countries, given the low per capita income, this ratio is high.

According to TÜIK report on population and housing, about $67 \%$ of households live in their owned properties, $24 \%$ in rented houses, $1,5 \%$ in free quarters (apartments provided for public officials). About $7 \%$ of the population do not own a house but do not pay rent (probably live in the houses belonged their families or relatives). The ratio of renters is highest in Istanbul by 31,5\% (TÜIK, 2011). The ownership is high compared with the average developed countries; $41 \%$ in Germany, 60\% in Japan, and 68\% in USA for instance (Proxenos, 2001). The ownership is higher than countries with high per capita income and well-organized mortgage systems. This may be due to the quality of housing and building costs. It should also be noted that the rising availability of mortgage loans could increase house prices tremendously and hence decrease the affordability of houses. Also the size of households is quite different (individuals per households 3,8 in Turkey, 2,2 in Germany, and 2,5 in USA).

\section{Model of Demand for Housing}

The importance of housing sector is twofold: One is that housing is an essential need for households, and if so, the demand for housing is expected to rise with population increases, and it would be expected that the demand for housing is income and price inelastic. However, as the quality and environmental characteristics of houses may differ, then as the income level rise, people prefer to move to better houses. Also, as the house prices decline, people would tend to change houses. On the other hand, house as an important component of real estate, may be a saving instrument, depending on the economic environment (see Megbolugbeet al. (1991) for a theoretical discussion).

Based on the abovementioned framework, and following a similar approach by Lee and Kong (1977) and Goodman (1988), let $D_{h}$ be the demand for housing, a log-linear model of demand for housing can be formulized as follows:

$$
D_{h}=e^{\alpha} \quad Y^{\beta} P^{\theta} N^{\pi}
$$

where $Y, P$, and $N$ represent income, house prices, and population respectively. Taking natural logarithm of (1), and adding a set of taste variables $\left(Z_{i}^{\lambda i}, i=1,2, \ldots, \mathrm{n}\right)$ and an error term, the model will be as follows: 


$$
\ln D_{h}=\alpha+\beta \ln Y+\theta \ln P+\pi \ln N+\sum_{i}^{n} \lambda_{i} Z_{i}+u
$$

The coefficients in (2) represent the elasticities of demand for housing: $\alpha$ is the constant term, $\beta$ is the income elasticity, $\theta$ is the price elasticity, $\pi$ is the impact of population on the demand for housing. The demand for housing may be affected by some other variables, such as households' tastes, interest rates, extra demand by foreigners, and public housing policies.

Equation (2) may be estimated by time-series (Lewis-Bynoeet al., 2008; Halicioğlu, 2005; Lebe and Akbaş, 2014), cross-sectional data (Leeuw, 1971) or household-based micro data (Alkay, 2008; Onder, 2010). The income may be the current real income, while in time-series analysis the permanent income is also considered (Attanasioet al., 2010). The house prices also may vary in time, and the house price indices may be above or under the average price level in the economy (Özsoy and Sahin, 2009). The price bubbles are usually tested in such a case.

The taste variables are unavoidably chosen according to the estimation method. For instance, a time-series data for a country cannot include personal tastes, as the data are aggregated. On the other hand, the interest rate will be implicitly included in the constant term in a cross-sectional analysis if the interest rate is the same in all the regions of a country.

\subsection{Data and Empirical Evidence}

The data used in this study is mainly from the Turkish Statistical Institute (TSI) in 2013. TSI publishes the data on the house sales on the provincial base. The data on population and regional value-added is also available. The data for social housing are collected from the Housing Development Administration of Turkey (HDA). The data on prices are only available at macro level as a housing sector price index, but it is not available either on average or as an index on the provincial or local base. ${ }^{2}$

The housing price data for provinces was collected from various advertising sources from internet. This data covers 1730 cases including 59 provinces. It should be noted that those prices are "ask prices", and it is assumed that the structure of the price data does not change even if the houses sold on a bargaining process. The average of the provinces is computed and an average price is determined for each province. The median has also been tested in the model.

The raw data included prices for flats and self contained houses. However, the range of prices for self-contained houses appeared to be very high. This is because all villa and slums are considered to be self contained houses, despite that those two types of houses are quite different in appliances and prices. So, the self-contained houses were excluded from the data. The data used in this study includes flats only. The data collected from İstanbul, Ankara, and İzmir each consists about $10 \%$ of the total sample (there consists about $30 \%$ of the whole). Those provinces were followed by Bursa, Trabzon, Manisa, Malatya, Tekirdağ, Aydın, Antalya, Bilecik and Mersin. The average price of flats in Turkey in the last quarter of 2013 is about 175,000 Turkish lira (about 60,000 dollar), and the median is 145,000 Turkish lira. The average size of flats is about $140 \mathrm{~m}^{2}$ (4 rooms on average). The average age of apartments is about 8 years

Table 2. Descriptive Statistics

\begin{tabular}{cccccc}
\hline & Mean & Median & Std. Dev. & Minimum & Maximum \\
\hline $\mathrm{D}_{\mathrm{h}}$ (house purchase) & 18.690 & 8.487 & 35.646 & 369 & 234.789 \\
$\mathrm{Y}$ (regional & 38.847 & 28.047 & 41.913 & 7.685 & 312.438 \\
value-added)(Thousands) & & & & & \\
$\mathrm{IW}$ (Income\&Wealth) & 0.43 & 0.45 & 0.165 & 0.02 & 0.88 \\
$\mathrm{P}$ (house prices) & 151.008 & 141.000 & 44.079 & 82.400 & 289.000 \\
$\mathrm{~N}$ (population)(Thousands) & 1.180 & 707 & 1.947 & 76 & 14.160 \\
$\mathrm{~F}$ (purchase by foreiners) & 201 & 0 & 802 & 0 & 5548 \\
$\mathrm{M}_{\mathrm{h}}$ (Purch. by mortgage) & 0,36 & 0,36 & 0,07 & 0,22 & 0,48 \\
$\mathrm{~S}_{\mathrm{h}(\text { total })}$ & 0,405 & 0,176 & 0,918 & 0,000 & 6,595 \\
$\mathrm{~S}_{\mathrm{h}(\text { low-income) }}$ & 0,122 & 0,092 & 0,114 & 0,000 & 0,498 \\
\hline
\end{tabular}

As seen in Table 2, about 18 thousand houses were purchased on average. Maximum sales have taken place in İstanbul, the biggest metropolitan city by over 14 million populations. Bayburt, the smallest city by about 75 thousands population, seems to be the smallest housing market. According to the regional income (measured by value-added),

\footnotetext{
2 The Central Bank of Turkey started to provide house price index for all provinces in 2015 . However our data has been collected in the last quarter of 2013 .
} 
İstanbul is the richest city, while Kars takes the lowest value. İstanbul seems to be the most expensive city in terms of average house prices (289.000TL), and Bilecik is the cheapest city by $82.400 \mathrm{TL}$.

Most of the houses purchased by foreigners are in Antalya, a touristic city in Mediterranean, followed by İstanbul, Muğla, and Aydın. Apart from İstanbul, all those cities are in the coast. Houses owned by mortgage credits consist about $36 \%$ of the total houses. The least mortgage credits demanded in Van, and the most in Denizli. The average ratio of social housing provided by HDA (TOKI) is about $40 \%$. The maximum ratio of social houses is in Van, the city where a severe earthquake took place in 2011. In some cities, such as Artvin, Isparta, Yalova, Aydın, and Mersin, HDA does not exist in housing market. About one-third of those houses were built for low-income groups. About half of the social houses are for low-income groups in some cities such as Van.

To establish a systematic relationship between those variables, equation (2) has been estimated by OLS technique, and the results are reported in Table 3. The model seems to fit quite well; F-statistic is significant at $1 \%$ level and adjusted $\mathrm{R} 2$ is above 0.80 in all regressions.

The model including income, price and population is estimated firstly (Reg.1). The results are as expected in the theory of demand; the income level of the region affect the demand for housing positively, and it is significant at 5\% level. The magnitude of the coefficient shows that the income elasticity of demand for housing is below unity, reflecting that it is income inelastic. Coefficient on house prices seems to affect the demand for houses negatively as expected; however, it is also below unity, reflecting price inelastic demand.

House ownership is also related to wealth accumulation, and the wealth effect may be even more important than the income effect. To test for the wealth effect, we have included a income \&wealth (IW) index in the regressions. This data is provided by the Turkish Statistical Office, and it includes both income and wealth. In Reg.2 both income and income \&wealth index have been included in the estimation. The effect of income \&wealth index offsets the impact of income, as it includes the income too. The impact is significantly positive and the magnitude of the coefficients is much higher than the coefficient for income only. This result shows that the effect of wealth is higher than the effect of income. This is consistent with the fact that the housing demand is at least partly related to wealth accumulation.

Table 3. Regression Analysis

\begin{tabular}{|c|c|c|c|c|}
\hline Variables & Reg. 1 & Reg. 2 & Reg. 3 & Reg. 4 \\
\hline \multirow[t]{2}{*}{ Constant } & $-3,45$ & 0,62 & 0,51 & 0,59 \\
\hline & $(3,13)$ & $(3,15)$ & $(2,44)$ & $(2,44)$ \\
\hline \multirow[t]{2}{*}{$\ln Y$} & $0,28 * *$ & $-0,005$ & & \\
\hline & $(0,13)$ & $(0,12)$ & & \\
\hline \multirow[t]{2}{*}{ IW } & & $1,95 * * *$ & $1,94 * * *$ & $1,92 * * *$ \\
\hline & & $(0,56)$ & $(0,54)$ & $(0,56)$ \\
\hline \multirow[t]{2}{*}{$\ln \mathrm{P}$} & $-0,49 * *$ & $-0,60 * * *$ & $-0,60 * * *$ & $-0,60 * * *$ \\
\hline & $(0,22)$ & $(0,23)$ & $(0,22)$ & $(0,22)$ \\
\hline \multirow[t]{2}{*}{$\ln N$} & $1,03 * * *$ & $1,14^{* * * *}$ & $1,14 * * *$ & $1,14 * * *$ \\
\hline & $(0,08)$ & $(0,08)$ & $(0,08)$ & $(0,07)$ \\
\hline \multirow[t]{2}{*}{$\ln F$} & $0,06 * * *$ & $0,03 *$ & $0,04 * *$ & $0,04 * *$ \\
\hline & $(0,02)$ & $(0,02)$ & $(0,02)$ & $(0,02)$ \\
\hline \multirow[t]{2}{*}{$\mathrm{M}_{\mathrm{h}}$} & $-0,66$ & $-1,53$ & $-1,53$ & $-1,50$ \\
\hline & $(1,00)$ & $(0,79)$ & $(0,75)$ & $(0,71)$ \\
\hline \multirow[t]{2}{*}{$\mathrm{S}_{\mathrm{h} \text { (total) }}$} & $-0,15^{* * *}$ & $-0,13^{* *}$ & $-0,13^{* *}$ & $-0,15^{* *}$ \\
\hline & $(0,05)$ & $(0,05)$ & $(0,05)$ & $(0,07)$ \\
\hline \multirow[t]{2}{*}{$\mathrm{S}_{\mathrm{h}(\text { low income) }}$} & $-0,14$ & $-0,18$ & $-0,19$ & \\
\hline & $(0,77)$ & $(0,67)$ & $(0,64)$ & \\
\hline $\mathrm{R}^{2}$ (Adjusted) & 0.84 & 0.88 & 0.88 & 0.89 \\
\hline S.E. of regression & 0.4844 & 0.4189 & 0.4147 & 0.4111 \\
\hline Sum sq. resid. & 11.967 & 8.7720 & 8.7724 & 8.7895 \\
\hline Log-likelihood & -36.654 & -27.491 & -27.493 & -27.550 \\
\hline F-statistic & $44.683 * * *$ & $54.570 * * *$ & $63.610^{* * *}$ & $75.503^{* * *}$ \\
\hline
\end{tabular}

The results are based on the White heteroskedasticity-consistent standard errors \& covariance.

Asterisks denotes significance at $* 10 \%, * * 5 \%$, and $* * * 1 \%$ levels.

The population affects the demand positively and significantly as expected and the elasticity is about unity. So, a $1 \%$ increase in population is associated with about a $1 \%$ rise in demand for houses. Although the size of the families may have impact on the number of dwelling in provinces, in a cross-section analysis, this result seems to be reasonable.

An extra demand comes from the foreigners particularly in the metropolitan cities and the coasts. The number of houses bought by foreigners has been included in the regressions, and the results show that a $1 \%$ increase in the demand by foreigners increases the total demand for houses about $0,06 \%$. This result is significant at $5 \%$ level in all regressions. 
The mortgage system is expected to increase the home ownership. Despite that the system has been inserted in the financial system of Turkey in 2007, the implementations still work as a simple credit system. This also may be regarded as an incentive for house owning. The ratio of houses sold on mortgage to total houses sold has been included in the regressions, and it seems to be insignificant. In various studies, interest rates has been used as an explanatory variables and found to be significant; while the interest rate decreases, the demand for house rises, and vice versa. However, in such a provincial based cross-section analysis, it is obvious that the interest rate is about the same in the whole country, and the share of mortgage credit does not seem to create any impact on the demand for housing (see İbicioğlu and Karan (2012) for a time-series analysis of Turkey).

Social housing provision is regarded to be more important than other policy tools towards housing sector, because it is a direct intervention. This has been implemented by the Housing Development Administration, providing houses to middle- and low-income groups (both included in Reg.3). The houses built for low-income groups do not seem to be significant, despite its negative sign. However, the ratio of total houses is negative and significant showing that a $1 \%$ increase in provision by HDA decrease the demand about 0,15\% (Reg.4). The HDA model is regarded to function as an umbrella rather than a competing body in the housing sector of Turkey. ${ }^{3}$ It seems that the houses targeting the low-income groups does not create any competitions with the private sector in housing sector. However, HDA does compete with the private sector by providing houses to the middle income groups. It seems that the housing program substitute about $15 \%$ of the market supply.

\section{Conclusion}

The demand in housing sector has been increasing in Turkey, fuelled by population growth, urbanization, and the demand by foreigners. As the construction sector is one of the main factors stimulating economic growth, government ought to take it serious, and implement adequate regulations and policies towards the sector. The most important steps taken in the last decade are the insertion of the mortgage system and public housing. The mortgage system works as a simple loan system, since the financial system is not as deep as expected. Unless the securitization of the system, the mortgage system would not significantly stimulate the housing sector. Our findings support this.

The other debate is the main task of the Housing Development Administration of Turkey (HDA). The main task recognized in public is the support for social housing for low- and middle-income groups. Those groups' income level is not high enough to own houses through a mortgage system, as the installments are high compared with their monthly wages, and the period for reimbursement is short. Our findings support the argument that the low-income groups would not have been able to own a house, unless the HDA did not provide apartments on convenient conditions. It seems that the public provision is unavoidable to provide adequate housing for low income groups, and to sustain an appropriate urbanization. On the other hand, the publicly provided houses targeted middle-income groups create crowding out effect on the housing market.

It should be noted that further studies should be implemented to establish a more systematic policy recommendations. We have carried out this study by the municipal-based data. Household-based studies are required to analyze the issue in more details. Given the high growth rates and increasing population and urbanization, the issue is going to be on the agenda for few decades. So, a research agenda should include more details regarding the housing sector in Turkey. No doubt that the public housing will be a significant part of such an agenda.

\section{Acknowledgements}

We thank to Betül Öktem for her assistance and three anonymous referees for their helpful comments.

\section{References}

Alkay, E. (2008). Housing Submarkets in İstanbul, International Real Estate Review, 11(1), 113-127.

Attanasio, O. P., Bottazzi, R. Low, H. Nesheim, W. L., \& Wakefield, M. (2012).Modelling the Demand for Housing over the Lifecycle.Review of Economic Dynamics, 15(1), 1-18.

Chen, J., Yang, Z., \& Wang, Y. P. (2014). The New Chinese Model of Public Housing: A Step Forward or Backward?, Housing Studies, 29(4), 534-550.

Chen, J., \& Nong, H. (2016).The heterogeneity of market supply effects of public housing provision: Empirical evidence from China, Journal of Housing Economics, forthcoming.

Coşkun, Y (2011). The Global Financial Crisis and the Turkish Housing Market: Is there a Success Story, Housing Finance International, 15(3), 6-14.

Coşkun, Y. (2010). An Analysis of the Strengths and Weaknesses of the Turkish Real Estate Market, MPRA Paper

\footnotetext{
${ }^{3}$ See the web-site of HDA (http://www.toki.gov.tr/english/index.asp).
} 
No.28361.

Davidson, A. (1999). Alternative Models of Social Housing: Tenure Patterns and Cost-renting in New Zealand and Sweden, Housing Studies, 14(4), 453-472.

De Leeuw, F. (1971). The Demand for Housing: A Review of Cross-Section Evidence, The Review of Economics and Statistics, 53(1), 1-10.

Glindro, E. T., Subhanij, T., Szeto, J., \& Zhu, H. (2011). Determinants of House Prices in Nine Asia-Pacific Economies, International Journal of Central Banking, 7(3), 163-204.

Goodman, A. C. (1998). An Econometric Model of Housing Price, Permanent Income, Tenure Choice, and Housing Demand, Journal of Urban Economics, 23, 327-353.

Halicioglu, F. (2005). The Demand for New Housing in Turkey: An Application of ARDL Model, Paper presented in 2005 Business and Economics Society International Conference, Grand Canyon, Arizona, USA.https://www.MdSS_SocialHousingPolicyReview.pdf

İbicioğlu, M., \& Karan, M. B. (2012). KonutKredisiTalebiniEtkileyenFaktörler: TürkiyeÜzerineBirUygulama, EkonomiBilimleriDergisi, 4(1), 65-75.

Lebe, F., \& Akbaş, Y. E. (2014). Türkiye'ninKonutTalebininAnalizi: 1970-2011, Atatürk ÜniversitesiİktisadiveİdariBilimlerFakültesiDergisi, 28(1), 57-83.

Lee, C. I. (2007). Does provision of public rental housing crowd out private housing investment? A panel VAR approach, Journal of Housing Economics, 16, 1-20.

Lee, T. H., \& Kong, C. M. (1977).Elasticities of Housing Demand, Southern Economic Journal, 44 (4),298-305.

Lewis-Bynoe, D., Archibald, X., \& Howard, S. (2008). An ARDL Model of the Demand for Housing in Barbados, Business, Finance \&Economics in Emerging Economies, 3(1), 151-174.

Megbolugbe, I. F., Marks, A. P., \& Schwartz, M. B. (1991). The Economic Theory of Housing Demand: A Critical Review, The Journal of Real Estate Research, 6(3), 381-393.

OECD (2011).Housing and the Economy: Policies for Renovation in Economic Policy Reforms, Chapter 4.

Olotuah, A. O., \&Bobadoye, S. A. (2009). Sustainable Housing Provision for the Urban Poor: A Review of Public Sector Intervention in Nigeria, The Built \& Human Environment Review, 2, 51-63.

Onder, Z. (2010). High Inflation and Returns on Residential Real Estate: Evidence from Turkey, Applied Economics, 32, 917-931.

Ören, K., \& Yüksel, H. (2013).Türkiye'deKonutSorunuveTemelDinamikleri, SüleymanDemirelÜniversitesiSosyalBilimlerEnstitüsüDergisi, 18, 1-38.

Özsoy, O., \& Sahin, H. (2009) Housing price determinants in Istanbul, Turkey: An application of the classification and regression tree model, International Journal of Housing Markets and Analysis, 2(2), 167-178.

Proxenos, S. (2001). Homeownership Rates: A global perspective. Housing Finance International, mimeo.

Quigley, J. M. (2006).Housing Policy in the United States, Program on Housing and Urban Policy, Working Paper No.W06-001.

Sengupta, U. (2015). Government intervention and public-private partnerships in housing delivery in Kolkata, Habitat International, fortcoming.

Shiller, R. (2007).Understanding recent trends in house prices and home ownership, NBER Working Paper, No. 3553.

Sinai, T., \& Waldfogel, J. (2005). Do low-income housing subsidies increase the occupied housing stock?,Journal of Public Economics, 89, 2137-2164.

Smith, D. A. (2012).Türkiye'de Dar GelirlileríçinKonut: DeğerlendirmeveÖneriler, Affordable Housing Institute, GYODER, İstanbul: StilMatbaacilı.

T. C. Ekonomi Bakanlığı (2014). Ekonomik Görünüm, Haziran, Eylül, Kasım 2014.

T. C. KalkınmaBakanlığı (2012-2014) GenelEkonomikHedeflerveYatırımlar.

TOKİ (2014-2015). KonutÜretimRaporu, https://www.toki.gov.tr/TR/Genel/dg.ashx?DIL=1\&BELGEANAH=261\&DOSYAISIM=ozet.pdf.

Tse, R. Y. C., C. Ho, W., \& Ganesan, S. (1999).Maching Housing Supply and Demand: An Empirical Study of Hong Kong's Market, Construction Management and Economics, 17, 625-633. 
TÜİK (2011). NüfusveKonutAraştırması, Sayı: 15843, 31 Ocak 2013.

Watson, E. (2013). A Closer Look at some of the Supply and Demand Factors Influencing Residential Property Markets, Reserve Bank of New Zealand Analytical Notes, AN 2013/11.

Whitehead, C., \& Scanlon, K. (2007). Social Housing in Europe, Christine Whitehead and Kathleen Scanlon (ed), Social Housing in Europe, London School of Economics and Political Science, London.

Wong, Y. C. R. (2002). Public Housing Reform and Its Effects on the Private Housing Market, Hong Kong Center Econ.Res. 71 (July/ August).

Yetgin, F., \& Lepkova, N. (2007).A comparative analysis on housing policies in Turkey and Lithuania, International Journal of Strategic Property Management, 11(1), 47-64.

\section{(cc) $\mathrm{BY}$}

This work is licensed under a Creative Commons Attribution 3.0 License. 